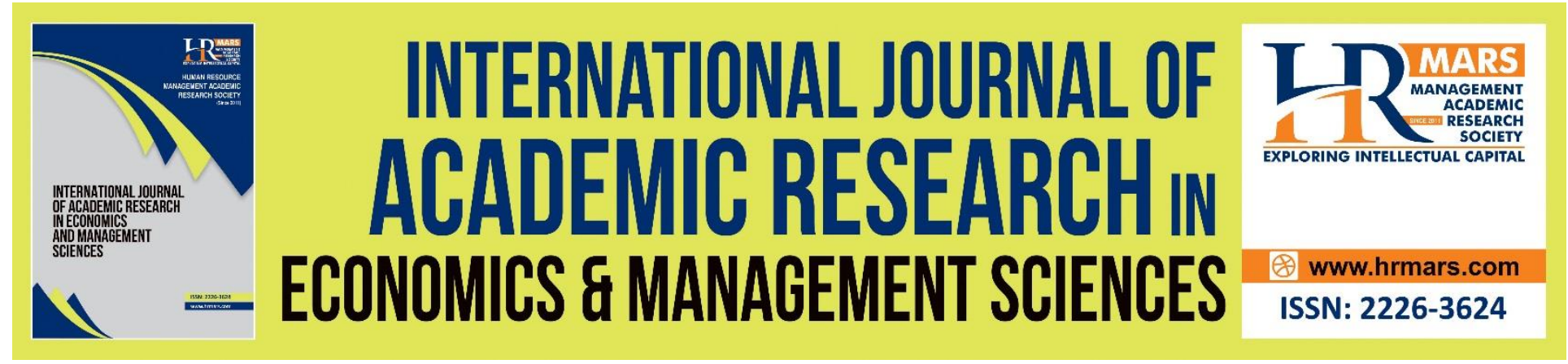

\title{
Unemployment, Immigrants, Price Level, Population and Crime: Cointegration Analysis of Malaysia
}

\section{Adibah Hussin, Nurul Nadia Abd Aziz, Roslilee Ab Halim, Mawarti Ashik Samsuddin}

To Link this Article: http://dx.doi.org/10.6007/IJAREMS/v9-i2/7354

DOI: 10.6007/IJAREMS/v9-i2/7354

Received: 23 March 2020, Revised: 26 April 2020, Accepted: 27 May 2020

Published Online: 28 June 2020

In-Text Citation: (Hussin et al., 2020)

To Cite this Article: Hussin, A., Aziz, N. N. A., Halim, R. A., \& Samsuddin, M. A. (2020). Unemployment, Immigrants, Price Level, Population and Crime: Cointegration Analysis of Malaysia. International Journal of Academic Research in Economics and Management Sciences, 9(2), 49-60.

Copyright: (c) 2020 The Author(s)

Published by Human Resource Management Academic Research Society (www.hrmars.com)

This article is published under the Creative Commons Attribution (CC BY 4.0) license. Anyone may reproduce, distribute, translate and create derivative works of this article (for both commercial and non-commercial purposes), subject to full attribution to the original publication and authors. The full terms of this license may be seen

at: http://creativecommons.org/licences/by/4.0/legalcode

Vol. 9, No. 2, 2020, Pg. 49 - 60

http://hrmars.com/index.php/pages/detail/IJAREMS

JOURNAL HOMEPAGE

Full Terms \& Conditions of access and use can be found at http://hrmars.com/index.php/pages/detail/publication-ethics 


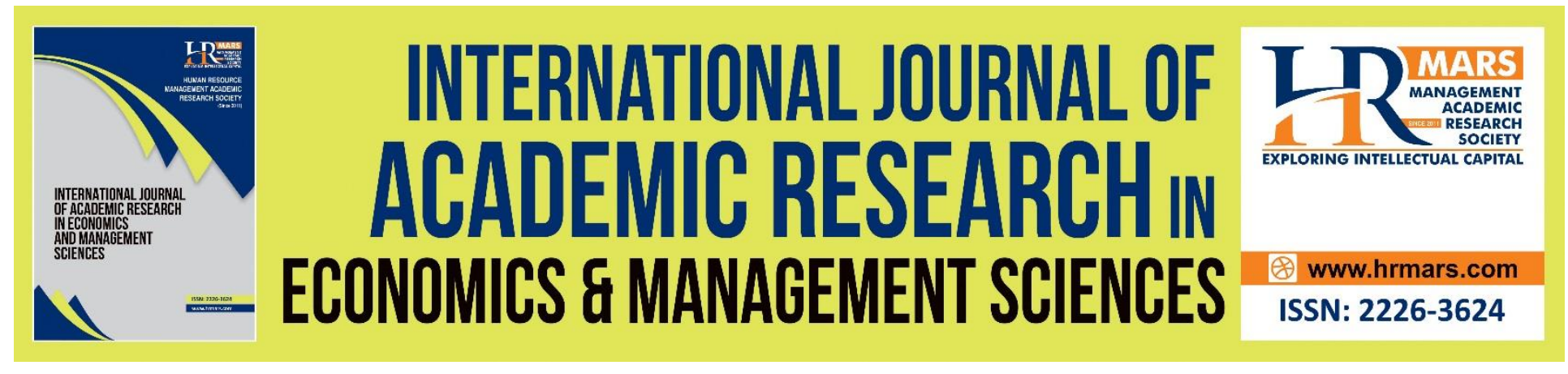

\title{
Unemployment, Immigrants, Price Level, Population and Crime: Cointegration Analysis of Malaysia
}

\author{
Adibah Hussin, Nurul Nadia Abd Aziz, Roslilee Ab Halim, Mawarti \\ Ashik Samsuddin \\ Faculty of Business and Management, Universiti Teknologi MARA Pahang Cawangan Jengka, \\ Pahang, Malaysia \\ Email: dibah575@uitm.edu.my,nurul_nadia@uitm.edu.my, roslilee@salam.uitm.edu.my, \\ mawarti@uitm.edu.my
}

\begin{abstract}
The crime index in Malaysia shown two distinctive overall trend patterns; increasing trend from 1982 to 2009 and decreasing from 2009 to 2016. On the other hand, the country's real GDP growth fluctuated substantially over the 34 years of period. Nevertheless, Malaysia has achieved its highest growth rate at $6.2 \%$ in the third quarter of 2017. Being a developing country with an open economy policy and industrialized market, it is, therefore, becoming important to study whether the economic condition does affect the crime rate in Malaysia. Hence, the purpose of this study is to investigate the relationship between economic variables (unemployment rate, price level, total immigrants, and population) and the crime index. Utilizing time-series data from the year 1982 to 2016 the study began with the analysing unit root test. The data must be proven stationary in order to proceed with other analyses. The cointegration analysis was done to capture the long-run equilibrium between variables. Findings showed that the economic variables investigated are crucial determinants and do impact the crime rate in Malaysia.

Keywords: Immigrant, Index Crimes, Price Level Population, Unemployment Rate.
\end{abstract}

\section{Introduction}

Crime is an act against the rule of law. Crime creates social problems such as property security, life-threatening, people will live in fear and affect the quality of life socially and economically (Ghani, 2017). Crime activities also may affect funding for the public and private sectors as the government had to spend the state budget for security and fighting crime. On top of that, although the crime index shows the decreasing rate starting from 2009 to 2016, this number still high as compared to other developed countries like Norway, Belgium, Japan, Finland, Switzerland, New Zealand, Austria, and Denmark. This situation would undermine the budget for more productive sectors such as education, training, research, and infrastructure development. Economically, criminal activity has an adverse effect on direct investment, squeezing job opportunities, and interfering with domestic economic growth. It may reduce firm 
INTERNATIONAL JOURNAL OF ACADEMIC RESEARCH ECONOMICS AND MANAGEMENT SCIENCES Vol. 9, No. 2, 2020, E-ISSN: 2226-3624 @ 2020 HRMARS

competitiveness due to increased operating costs such as having to increase the cost of insurance premiums, the cost of installing security alarms or hiring security guards (Detotto \& Pulina, 2013).

In Malaysia, although the Sun Daily dated 23rd May 2017 reported that the crime rate showed a decreasing annual trend of $9 \%$ between 2010 to 2017. Datuk Acryl Sani Abdullah Sani, the director of Bukit Aman Community and Crime Prevention Department, in a press conference after launching the Security Crime Prevention Campaign \& Exhibition 2016 program said a total of 38,877 crime cases were recorded in Malaysia from January to April 2016, an increase of 4.6 percent compared to the same period last year (Bernama, 2016). Of the total, nearly 6,662 cases were burglary crimes (58 percent), 12,216 cases were motor vehicle theft and 3,656 cases were car-breaks. The scenario has been a source of concern and calls for attention for researchers to study the factors that influence crime rates so that effective enforcement policies can be proposed (Tang \& Darit, 2015). Previous researchers highlighted the association of crime rates to unemployment (Altindag, 2012; Andresen, 2012; Britt, 1994; Ghani, 2017; Jawadi, Mallick, Cheffou, \& Augutine, 2019), inflation rate (Rosenfeld, Vogel, and McCuddy, 2019; Lobont, Nicolescu, Moldovan \& Kuloglu 2017), immigrants (Pinotti, 2015; Ramos and Wenger, 2018), and populations (Ha \& Andresen, 2017; Janko and Popli, 2015).

Looking at the existing study, most studies use the different variables as determinants of crime and no study has focused on the relationship between crime with the unemployment rate, price level, immigrants and population. On the other hand, in the case of Malaysia, the empirical study on crime is relatively few. This study, therefore, intends to have better insights on how these economic variables affecting the crime rate in Malaysia by looking at the impact of the country's unemployment rate, price level, immigrants and population on crime index and will discuss it from economist perspectives. In Malaysia, these variables are contributing to the crime rate in Malaysia.

\section{Review of Related Literature}

Most cases of crime in Malaysia include motor vehicle theft, burglary, snatch theft, and violent crime (Ghani, 2017). The level of crime has been associated with various factors including economy complexity (Madni \& Khan, 2019), the inefficiency of the institution (Madni \& Khan, 2019), inflation (Tang, 2009; Gillani, Rehman \& Gill, 2009), unemployment (Janko \& Popli, 2015), population (Boatner, 2019; Briseño \& Rojas, 2020; Madni \& Khan, 2019), urbanization (Bennett, 1991; Briseño \& Rojas, 2020; Ghani, 2017) and migration (Sidhu, 2005).

The existence of empirical inquiries on a strong relationship between unemployment and crime has been more than a hundred years in the social science literature (Cantor \& Land, 1985). Economic theory foresees the existence of a positive relationship between unemployment and crime. Hence, in France and UK, the unemployment shocks drive crime rates and persistent unemployment give more impact on criminality than the short-term fluctuation in the labor market (Jawadi, Mallick, Cheffou, \& Augustine, 2019). Consistent with a standard economic model of criminal behavior, (Prescott \& Pyle, 2019) the authors found that a higher unemployment rate has a causal relationship with higher property crime rates and higher wages may result in a lower crime. In addition, using the predictive analysis (Alves, Ribeiro \& Rodrigues, 2018), the random forest algorithm determines one of the variables of urban indicators to predict crime in Brazilian cities for describing homicides is unemployment. Furthermore, (Fallesen, 
Geerdsen, Imai \& Tranaes, 2018) unemployment has a high causal impact on rearrests for individuals with criminal records who are active in the labor market. Evidence from Greece concluded that the unemployment rate affects the overall criminality considerably, but criminality was not confirmed on specific type crimes on the assumption that recession would rise (Laspa, 2013).

A number of researchers include inflation rate as determinants of crime (crime (Rosenfeld, Vogel, and McCuddy, 2019; Umair, 2019; Lobont, Nicolescu, Moldovan \& Kuloglu 2017; Tang, 2009; Gillani, Rehman \& Gill, 2009). Price stability is important to ensure the prosperity of a country. If the prices keep on increasing, it will burden the city where some may involve in crime to survive. Rosenfeld, Vogel, and McCuddy (2019) investigated the link between crime and inflation in United States cities. This study used annual data from 1960 to 2013. They found that there are significant effects of the inflation rate on the crime rates in the 17 cities in the United States. Another study by Lobont et. al (2017), investigated the effects of socioeconomics factors on the crime rate in Romania. The results revealed that there is granger cause from inflation to the crime rate. This finding was supported by Gillani, Rehman, and Gill (2009). They examined the factors that may contribute to the positive trend of crime in Pakistan from 1996 to 2007. The analyses revealed that there is a long-run equilibrium between inflation and crime. Furthermore, Granger causality showed that price level caused crime and it is unidirectional causality from inflation to crime. In Malaysia's case, a study by Tang (2009) investigated the link between inflation and crime rates in Malaysia. From the analyses, he found that inflation is positively related to the crime rate in the long run; but in the short run, inflation is not significant. While for the causality test, he found that there is unidirectional direction only; whereby it is running from inflation to crime. On the other hand, Umair (2019) found different findings for the Pakistan case. His study found that there is a negative relationship between price and crime in the short-run and no long-run relationship exists.

Other than that, immigrants can be a factor contributing to a higher rate of crime. Malaysia's long history of immigration rooted back to the years before independence where traders from China, India, and Arabs settled in Malacca in the 1600s. These were followed by several significant phases of immigration in Malaysia. Over the years the number of foreign immigrants increased substantially. With the increasing number of foreign immigrants in Malaysia, the citizens are getting more concerned about the issue of safety and its impact on the crime rate. A study in Finland by Salmi, Kivivuori and Aaltonen (2015) found that some acts of delinquency were more prevalent among immigrants than native youth. In Italy, a study showed immigrant legalization reduces the crime rate of legalized immigrants (Pinotti, 2017). An investigation of immigration-crime relationships in metropolitan areas by Adelman, Reid, Markle, Weiss and Jaret (2017) using more than 40 years of data indicate that immigration is consistently linked to decreases in violent crime and property crime throughout the time period. While Ramos and Wenger (2018) stated that the negative association between immigration and crime in contemporary research is when using only one level of analysis without regard for how this relationship might vary when analyzed across multiple levels of analysis simultaneously. Using hierarchical Poisson Regression they found that the result depends on the level of analysis; a positive immigration-crime link at the tract level but negative at the city level. The result is also supported by Kubrin, Hipp and Kim (2018) when they also found considerable insights by distinguishing between diverse groups of immigrants. 
However, the increase in criminal cases involving foreigners in Malaysia has raised concerns. The Star newspaper dated 16 October 2019 has reported a police record of 42,451 criminal cases involving foreigners between 2016 and August 2019 ranging from theft (12,647 cases), followed by house break-ins (11,862 cases) and motorcycle theft ( 4,822 cases). According to Pook (2016), the number of illegal immigrants in Malaysia might be bigger than the official number released by the government. He highlighted the estimation released by the Malaysian Employers Federation (MEF) that the number of legal and illegal immigrants in Malaysia might go up as much as 6 million.

Besides, there are several studies that measure the effects of population on crime rates such as population size (Hashim et al., 2019; Krieger \& Meierrieks, 2019), population density (Ha \& Andersen, 2017), age of citizen (Janko \& Popli, 2015), race and ethnicity (Boatner, 2019), and rate of urbanization population (Hashim et al., 2019). A study done by Boatner (2019) found that criminal records committed by black men and white men may affect the labor market outcomes. She argued that the population factor (race and ethnicity) may affect the employment outcomes of a country. Some researchers use population variables by categorizing populations according to age and measure their impact on crime rates. For instance, Janko and Popli (2015) found that an increase in the rate of young men (18-24 years) in the population led to an increase in the incidence of robbery. Meanwhile, an increase in the population of men aged 25-44 years old showed a positive correlation with the rise in the crime rate of violence and other property crimes like breaking and entering and fraud. The other researchers measure the effect of population density variables on crime rates. Ha and Andresen (2017) found that population density has a positive relationship with theft. A study of Hisham et al (2019), however, found that the effect of population density on the crime index rate is not significant. Furthermore, the more recent researchers (Briseño \& Rojas, 2020) have measured the effects of the population on electricity theft and they found that an increase of one million in the population will increase the theft of electricity by five. Their findings are consistent with Hashim et al (2019) who found that the rate of urbanization and population size contributes 56 percent variance in crime index rate incident.

\section{Methodology}

In conducting this paper, the data mainly get through the International Financial Statistics website, Department of Statistics Malaysia, and Ministry of Home Affairs. The data that were annual data for Malaysia from 1982 to 2016. The dependent variables are using the total index crime cases for Malaysia. Index crime divided into two, which are violent crime and property crime. It includes murder, rape, robbery, serious attack, burglary, larceny, motor vehicle theft, arson, and others. This study focuses on this index crime since the Royal Malaysian Police (RMP) has mentioned that, they are using the term index crime as a measure for the general crime situation in Malaysia since it contributes mostly to the crime rate in Malaysia (ACP Amar Singh Sidhu, 2015).

For independent variables, this paper uses the unemployment rate, price level, immigrants and population. The unemployment rate refers to the rate of people who are currently unemployed but actively searching for a job. Meaning that, they are included in the labor force, however currently unemployed. This variable has been included since there is a strong relationship between unemployment and crime (Lobont et. al., 2017). For the price level, this paper uses the Consumer Price Index $(C P I=2000)$. CPI was calculated by taking price changes 
for each item in the predetermined basket of goods and averaging them. When price level increases, it is a signal that the cost of living also increases, and thus it may contribute to the increment in the crime rate. The next variable is immigrants. For this variable, this study is considering the legal immigrants only since the data on illegal immigrants is very difficult to trace. It is the value of total immigrants in Malaysia. Lastly, the variables are population. It refers to the total population of Malaysian aged between 15 to 64 years old only. A study found that an increase in population will increase crime cases (Ha and Andresen, 2017).

This study employs time series data and therefore the data must be tested for stationery using unit root test to avoid spurious results. If the estimated variables are not stationary, the regression results with these non-stationary variables are spurious. The test will use the Augmented Dickey-Fuller test (ADF). The ADF consists the estimating the following regression;

$$
\Delta Y t=\beta 1+\beta 2 t+\delta Y t-1+\alpha i \Sigma \Delta Y t-i+\varepsilon t
$$

Where $Y t$ is our variable under investigation, $\Delta$ is the differencing operator, $\{\beta 1, \beta 2 t, \delta, \alpha 1$, $\alpha \mathrm{m}\}$ is the set of parameters to be estimated, $\varepsilon \mathrm{t}$ is a random error term and where $\Delta Y \mathrm{Yt}-1$ $=(\Delta \mathrm{Yt}-1-\Delta \mathrm{Yt}-2), \Delta \mathrm{Yt}-2=(\Delta \mathrm{Yt}-2-\Delta \mathrm{Yt}-3)$, etc. The null hypothesis of unit root tests is as follows:

$\mathrm{HO}: \delta=0$ ( $\mathrm{tt}$ is nonstationary or there is unit root)

$\mathrm{H} 1: \delta<0$ (Yt is stationary or non- unit root)

If the null hypothesis cannot be rejected, the variables are not stationary and contain unit-roots. Meaning that the data may have trends, cycles, random walks, or a combination of three. Therefore, the result may be meaningless, whereby it may indicate a relationship between variables that do not exist.

Hence, it has to be different $d$ times to make it stationary. If the variables found to be integrated at the same level, the study will proceed with cointegration. For this analysis, empirical studies mostly employed the Engle and Granger (1987) and Johansen and Juselius (1990) methods. Johansen and Juselius test apply the maximum likelihood estimation of the VAR model to determine the number of cointegrating vectors. Trace test statistics and Max Eigenvalue statistics will be used to determine the number $(r)$ of cointegrating vectors. For this study, we employ the concept of cointegration to investigate the long-run equilibrium between the variables using the maximum likelihood approach of the Johansen and Juselius method. The analysis will be based on the following equations.

CRIMEt $=\beta 1+\beta 2 U R t+\beta 3 \ln I M M I t+\beta 4 P R I C E t+\beta 5 \ln P O P t+u t$ Where InCRIMEt is the natural log of total index crime, URi is the unemployment rate, InIMMIt is the natural log of total immigrants in Malaysia, PRICEt is the Consumer Price Index, InPOPt is the natural log of total population and $\mu \mathrm{t}$ is the stochastic error term.

To perform the cointegration test, the null hypothesis as there is no cointegration among variables. If trace statistics exceed the critical value, the null hypothesis will be rejected. This would mean that cointegration exists between variables. 
Then, if the variables cointegrated, it implies that there must exist causality among the variables, at least in one direction. This paper will employ the Granger causality test. The causality test will help in determining whether a change in any series can be explained by the other series. All variables will be in the first difference since they must be integrated at the same level and need to be stationary. Next, to analyze the causal relationship, this study estimates a vector error correction model (VECM). It can be expressed as follows.

$$
\text { k1 k2 k3 k4 }
$$

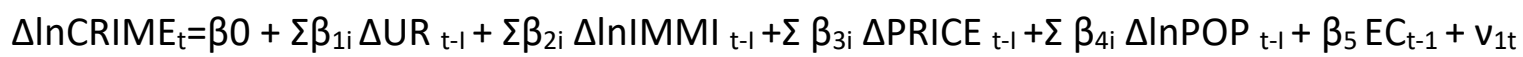

$$
i=1 \quad i=1 \quad i=1 \quad i=1
$$

Where $\Delta$ LnCRIME is the first difference of the natural log of total crime index (CRIME), $\Delta$ UR is the first difference of the unemployment rate (UR), $\Delta$ IMMI is the first difference of the immigrants (IMMI), $\triangle$ PRICE is the first difference of the consumer price index (PRICE) and $\triangle \operatorname{InPOP}$ is the first difference of the natural log of the population (POP). ECt-1 is the error correction term that is derived from the long-term cointegrating relationship. Therefore, the estimated coefficient of ECT ( $\beta 5$ ) measures the long-run relationship if the t statistic is significance while $\beta 1$, $\beta 2, \beta 3$, and $\beta 4$ measure the short-run causal relation by the significant of joint $F$ statistics. The structure lag is determined by using Akaike's minimum Final Prediction Error (FPE) criterion. From this causality test, this study able to analyze if there are bidirectional or unidirectional causality exists between variables.

\section{Results and Discussion}

This paper utilizes time-series data from 1982 to 2016. Therefore, the stationarity test must be conducted. For this analysis, the null hypothesis, Ho = has a unit root test (nonstationary) cannot be rejected at the level of significance. However, as the data being difference at the first difference, the null hypothesis is rejected. Therefore, the ADF and PP test results for the first difference indicate that all variables are I (1). Meaning that, after the first difference, there is no evidence of the existence of unit roots in either the ADF or the PP tests for all variables

\begin{tabular}{|c|c|c|c|c|}
\hline \multicolumn{5}{|c|}{$\begin{array}{c}\text { Table } 1 \\
\text { Stationarity Test }\end{array}$} \\
\hline & \multicolumn{2}{|c|}{ ADF } & \multicolumn{2}{|c|}{ PP } \\
\hline & Level & 1st Diff & Level & 1st Diff \\
\hline InCRIME & -1.6413 & $-3.1418^{* *}$ & -1.5643 & $-3.1617 * *$ \\
\hline UR & -1.4016 & $-4.3507 * * *$ & -1.8282 & $-4.2913 * * *$ \\
\hline InIMMI & -1.2983 & $-5.535 * * *$ & -1.3 & $-5.5361 * * *$ \\
\hline PRICE & 2.02388 & $-4.588 * * *$ & 1.76987 & $-4.6945 * * *$ \\
\hline InPOP & -1.2983 & $-5.535 * * *$ & -1.3 & $-5.5361 * * *$ \\
\hline
\end{tabular}
as in table 1 below. 
Notes: Where InCl, UR, InIMMI, PRICE and InPOP are Crime Index, Unemployment Rate, Total Immigrants, CPI and Total Population respectively. Numbers in the table are the t-statistics for testing the null hypothesis that the variables have a unit root or are non- stationary.

$* *$ indicate the significance level of $5 \%$

$* * *$ indicate the significance level of $1 \%$.

Since the data is integrated at the same level, this study will continue with the cointegration test. For non-stationary variables, the short-run equilibrium may bring spurious results; therefore, the researcher can look at the long-run equilibrium. Cointegration testing is employed to capture the long-run equilibrium relationship of the variables. Table 2 presents the Johansen cointegration test at selected lag levels from the minimum of Schwartz criterion (SC), which is at lag 2. The null hypotheses of non-cointegration are rejected, suggesting that at least one cointegrating vector exists.

\begin{tabular}{|c|c|c|c|c|c|c|}
\hline \multicolumn{7}{|c|}{$\begin{array}{c}\text { Table } 2 \\
\text { Cointegration Test }\end{array}$} \\
\hline \multirow{2}{*}{\multicolumn{2}{|c|}{ Vector }} & \multicolumn{3}{|c|}{ (InCRIME, UR, InIMMI, CPI, InPOP) } & \multirow{3}{*}{$\begin{array}{c}5 \\
\text { Percent } \\
\text { Critical } \\
\text { Value } \\
\text { (trace) }\end{array}$} & \multirow{3}{*}{$\begin{array}{l}5 \text { Percent } \\
\text { Critical } \\
\text { Value } \\
\text { (max- } \\
\text { eigen) }\end{array}$} \\
\hline & & \multirow{2}{*}{ Eigenvalue } & \multirow{2}{*}{$\begin{array}{c}\text { Trace } \\
\text { Statistic }\end{array}$} & \multirow{2}{*}{$\begin{array}{l}\text { Max-Eigen } \\
\text { Statistic }\end{array}$} & & \\
\hline Ho & $\mathrm{Hi}$ & & & & & \\
\hline$r=0$ & $r>0$ & 0.80371 & $129.9212^{*}$ & 52.10119* & 69.81889 & 33.87687 \\
\hline$r \leq 1$ & $r>1$ & 0.764527 & 77.81997* & $46.27715^{*}$ & 47.85613 & 27.58434 \\
\hline$r \leq 2$ & $r>2$ & 0.377761 & $31.54282^{*}$ & 15.18181 & 29.79707 & 21.13162 \\
\hline$r \leq 3$ & $r>3$ & 0.281689 & $16.36102 *$ & 10.58729 & 15.49471 & 14.2646 \\
\hline$r \leq 4$ & $r>4$ & 0.165088 & 5.773729* & 5.773729* & 3.841466 & 3.841466 \\
\hline
\end{tabular}

Notes: $r$ indicates the number of cointegrating vectors.

Critical values are taken from Johansen \& Julius 1990

* denotes rejection of the hypothesis at $5 \%$ significance level.

From table 2 above, the cointegration rank test suggesting at most two cointegrating variables exist at $5 \%$ significance level. The result recommends that these variables are bound together by long-run equilibrium relationships and follow a common long-run path. Meaning that, in the long run, the unemployment rate, immigrants, price level, and population have an impact on crime. All these results indicate the long-run cointegration regression, thus we would elaborate these results by using the equation in equation (3). So, generally, the cointegration equations are represented as follows:

$$
\begin{gathered}
\text { InCRIME }=-7804.04+34.09 \mathrm{UR}-50.564 \mathrm{InIMMI}+1.648 \mathrm{PRICE}+464.277 \mathrm{InPOP} \\
(5.31294) \quad(25.3052)
\end{gathered}
$$

Notes: Standard error is in parentheses. 
All coefficients are highly significant at $1 \%$ significance level. The equation above shows the unemployment rate (UR), price level (PRICE) and population (InPOP) are positively related to CRIME.

As the unemployment rate increases by $1 \%$, the index crime estimated to increase by $34.09 \%$. Being unemployed, people lost a source of income. The need for survival sometimes forces people to be irrational and eventually committing to crime. Therefore, when the unemployment rate increase, the opportunity to earn money reduces and thus push the individuals to commit a crime to get immediate money. In terms of the price level, a $1 \%$ increase in consumer price index (CPI), index crime increases by $1.648 \%$. CPI measures the overall price of goods and services in a country, consumed by a typical individual. Economists use the CPI to monitor changes in the cost of living. An increase in the cost of living reduces real income. Consequently, it reduces the purchasing power of an individual. Individuals who unwilling to downgrade the current living style might end up finding unlawful alternative solutions and involving in crime. Tang (2009) and Gillani, Rehman, and Gill (2009) stated that if price levels keep on increasing, it will burden the citizen and they may commit a crime to maintain their life. A high-density population opens up the opportunity to commit a crime. The positive relationship between population and crime explains that, as population increase by $1 \%$, index crime will increase by $464.277 \%$. Most of the Malaysian population aged 15 to 64 years old. As the population increase, the process of urbanization happens. At the same time, living style and living cost also increase which may lead to criminal activities. According to Janko \& Popli (2015), an increase in the rate population of men aged 8-44 years) will lead to an increase in the crime. The result supports the study of (Madni \& Khan, 2019) who found the positive relationship between population growth and crime. Our study's finding also consistent with Briseño and Rojas (2020) who found that the changes in electricity theft in Mexico are determined by changes in population. The possible explanation is that as population increase, the process of urbanization happens. At the same time, living style and living cost also increase which may lead to criminal activities (Krieger \& Meierrieks, 2019). Meanwhile, for immigrants, the result shows a negative impact on index crime. A $1 \%$ increase of immigrants, index crime is estimated to reduce by $50.564 \%$. As Malaysia is aiming to be a high-income and developed nation by 2020; where the demand for foreign workers to fulfil industry's vacancies is expected to escalate; it seems that foreign workers will be able to integrate into the economic transformation of the country. However, this study utilized data of legal immigrants, therefore crimes that involve illegal foreign workers command special attention.

Since the variables found to be cointegrated, the study will proceed to Granger Causality test since there must be Granger causality in at least one direction to hold the long-run relationship. The test based on the vector error correction model as in the below table (Table 3). 
INTERNATIONAL JOURNAL OF ACADEMIC RESEARCH ECONOMICS AND MANAGEMENT SCIENCES Vol. 9, No. 2, 2020, E-ISSN: 2226-3624 @ 2020 HRMARS

\begin{tabular}{|l|c|c|c|c|c|}
\hline \multicolumn{7}{|c|}{ Table 3 } \\
Granger Causality Test \\
\hline $\begin{array}{c}\text { Dependent } \\
\text { Variable }\end{array}$ & dInCRIME & Dur & dInIMMI & dPRICE & dlnPOP \\
\hline dInCRIME & - & 1.13 & $5.58^{*}$ & 1.66 & 0.05 \\
\hline dUR & 1.828943 & - & - & - & - \\
\hline dlnIMMI & 2.54443 & - & - & - & - \\
\hline dPRICE & $10.67497^{* * *}$ & - & - & - & - \\
\hline dInPOP & 0.359151 & - & - & - & - \\
\hline
\end{tabular}

Note: * indicate the significance level of $10 \%$

$* *$ indicate the significance level of $5 \%$.

$* * *$ indicate the significance level of $1 \%$.

This study found granger causality between dInCRIME and dInIMMI. Besides, it also found the granger causality between dPRICE and dInCRIME. These results imply that the causality direction is happening from immigrants or foreign workers to crime. While the direction from crime, the causality is running from crime to price. For the other variables, there is no evidence of Granger causality exist. This study seems consistent with the study by Tang (2009) whereby he found that the crime rate in Malaysia is significantly affected by changes in price.

\section{Conclusion}

The trend of crime index in Malaysia has two distinctive patterns; increasing (from the year 1982-2009) and decreasing (the year 2009-2016). While the country's economic growth fluctuated substantially over the 34 years of period. The scenario draws researchers' attention to seek better insights on how economic variables influence the crime rate in Malaysia. Being a developing country with an open economy policy and industrialized market, it is crucial for Malaysia to preserve economic stability and a peaceful country to ensure investment growth from both domestic and foreign investors.

Four economic variables (unemployment rate, price level, population, and immigrants) were investigated to see the impact they have on the crime index in Malaysia. All normalized coefficients are highly significant at a $1 \%$ significance level which portrays all determinants studied has related crime in this country. While the unemployment rate, price level, and population have positively related to the crime index, immigrants showed an adverse impact. In addition, the result of Granger causality also showed that Malaysia's index crime is granger caused by price and immigrants are granger caused by index crime.

Unemployment and inflation have always been issues of concern to Malaysians. In spite of having a very low unemployment rate, issues of unemployment among young adults need to be addressed. In 2017 unemployment is only around 3.4\% but the youth unemployment rate is over three times higher at around $10.8 \%$ (Dass, 2018). The escalating inflation rate made the scenario worsen. Higher price for housing and food increases the burden and the cost of living. It is very alarming and disturbing to see a high number of young people who still live in poverty despite having a job. While the rising numbers of illegal foreign workers in Malaysia needed greater foreign worker's regulations' implementation and enforcement. An influx of a higher 
INTERNATIONAL JOURNAL OF ACADEMIC RESEARCH ECONOMICS AND MANAGEMENT SCIENCES

Vol. 9, No. 2, 2020, E-ISSN: 2226-3624 ㄷ 2020 HRMARS

number of legal foreign workers could foster the industry growth and help Malaysia to achieve its goal. Strong efforts are needed to achieve sustainable economic growth and prosperity in the country.

\section{References}

Adelman, R., Reid, L. W., Markle, G., Weiss, S., Jaret, C. (2017). Urban Crime Rates and the Changing Face of Immigration: Evidence Across Four Decades. Journal of Ethnicity in Criminal Justice, 15(1), 52-77.

Altindag, D. T. (2012). Crime and unemployment: Evidence from Europe. International Review of Law and Economics, 32(1), 145-157. http://doi.org/10.1016/j.irle.2011.10.003.

Andresen, M. A. (2012). Unemployment and crime: A neighborhood level panel data approach. Social Science Research, 41(6), 1615-1628.

Bernama. (2016). Kes jenayah indeks meningkat 4.5\% sehingga April tahun ini. Utusan Online. http://www.utusan.com.my/berita/jenayah/kes-jenayah-indeks-meningkat-4-6sehingga-april-tahun-ini-1.319570

Bennett, R. R. (1991). Development and Crime: A Cross-National, Time-Series Analysis of Competing Models. Sociological Quarterly, 32(3), 343-363. http://doi.org/10.1111/j.1533-8525.1991.tb00163.x

Boatner, J. (2019). Population with Criminal Records and Racial Disparity in Labor Markets. IZA Journal of Labor Policy, 9(1). http://doi.org/10.2478/izajolp-2019-0002

Briseño, H., Rojas, O. (2020). Factors associated with electricity theft in Mexico. International Journal of Energy Economics and Policy, 10(3), 250-254. http://doi.org/10.32479/ijeep.9002

Britt, C. L. (1994). Crime and Unemployment Among Youths in the United States, 1958-1990: A Time Series Analysis. American Journal of Economics and Sociology, 53(1), 99-109.

Cantor, D., Land, K. (1985). Unemployment and Crime Rates in the Post-World War II United States: A Theoretical and Empirical Analysis. American Sociological Review, 50(3), 317332.

Carvalho, M., Sivanandham, H., Rahim, R., Tan, T. (2019). Foreigners Committed over 42000 Crimes in Malaysia since 2016. The Star. $\mathrm{h}$

https://www.thestar.com.my/news/nation/2019/10/16/foreigners-committed-over-42000crimes-in-malaysia-since-2016-says-home-ministry.

Dass, A. (2018). Young and jobless in Malaysia. The Star.

https://www.thestar.com.my/business/business-news/2018/08/06/young-and-jobless-inmalaysia/\#ZSeBTGrvdmpTqp8I.99.

Detotto, C., \& Pulina, M. (2013). Does more crime mean fewer jobs and less economic growth? European Journal of Law and Economics, 36(1), 183-207.

Fallese, P., Geerdsen, L. P., Imai, S., Tranaes, T. (2018). The effect of active labor market policies on crime: Incapacitation and program effects. Labour Economics, 52, 263-286.

Ghani, Z. A. (2017). A comparative study of urban crime between Malaysia and Nigeria. Journal of Urban Management, 6(1), 19-29.

Gillani, S. Y. M., Rehman, H. U., \& Gill, A. R. (2009). Unemployment, Poverty, Inflation and Crime Nexus: Cointegration and Causality Analysis of Pakistan. Pakistan Economic and Social Review, 47(1), 79-98. 
Ha, O. K., \& Andresen, M. A. (2017). Unemployment and the specialization of criminal activity: A neighborhood analysis. Journal of Criminal Justice, 48, 1-8.

Janko, Z., \& Popli, G. (2015). Examining the link between crime and unemployment : a time-series analysis for Canada Examining the link between crime and unemployment : a time-series analysis for Canada. Applied Economics, 6846(May), 4007-4019.

Jawadi, F., Mallick, S. K., Cheffou, A. I., Augustine, A. (2019). Does higher unemployment lead to greater criminality? Revisiting the debate over the business cycle. Journal of Economic Behavior \& Organization. https://doi.org/10.1016/j.jebo.2019.03.025.

Krieger, T., \& Meierrieks, D. (2019). Population size and the size of government. European Journal of Political Economy. http://doi.org/10.1016/j.ejpoleco.2019.101837.

Kubrin, C. E., Hipp, J. R., \& Kim, Y. (2018). Different than the Sum of Its Parts: Examining the Unique Impacts of Immigrant Groups on Neighborhood Crime Rates. Journal of Quantitative Criminology, 34, 1-36.

Laspa, C. (2013). Do the economic factors affect criminality? Evidence from Greece, 1991-2010. European Journal of Law and Economics, 39(1), 107-118.

Lobont, O. R., Nicolescu, A. C., Moldovan, N. C., \& Kuloglu, A. (2017). The Effect of Socioeconomic Factors on Crime Rates in Romania: A Macro Level Analysis. Economic ResearchEkonomska Lstrazivanja, 30 (1), 91-111.

Madni, G. R., \& Khan, B. (2019). Siege of violent crimes through economic complexity and institutions. International and Multidisciplinary Journal of Social Sciences, 8(2), 146-163. http://doi.org/10.17583/rimcis.2019.4147

Pinotti, B. P. (2017). Clicking on Heaven's Door: The Effect of Immigrant Legalization on Crime. American Economic Review, 107(1), 138-68.

Pinotti, B. P. (2015). Immigration Enforcement and Crime. American Economic Review, 105(5), 205-209.

Pook, A. L. (2016). The dilemma of having foreign workers in Malaysia. The Straits Times. https://www.straitstimes.com/opinion/the-dilemma-of-having-foreign-workers-inmalaysia.

Prescott, J. J., Pyle, B. (2019). Identifying the impact of labor market opportunities on criminal behaviour. International Review of Law and Economics, 59 (September), 65-81.

Ramos, J., Wenger, M. (2018). Effects in Disguise: The Importance of Controlling for Constructs at Multiple Levels in Macro-Level Immigration and Crime Research. City \& Community, 17(4), 1100-1118.

Rosenfeld, R., Vogel, M., \& McCuddy, T. (2019). Crime and Inflation in U. S. Cities.J Quant Criminol, 35, 195-210.

Salmi, V., Kivivuori, J., \& Aaltonen, M. (2015). Correlates of Immigrant Youth Crime in Finland. European Journal of Criminology, 12(6), 681-699.

Sidhu, A. S. (2005). The Rise Of Crime In Malaysia An Academic And Statistical Analysis. Journal of the Kuala Lumpur Royal Malaysia Police College, 1, 1-28.

Tang, C. F., \& Darit, S. M. (2015). Penentu Makroekonomi Kadar Jenayah di Malaysia. Jurnal Ekonomi Malaysia, 49(2), 53-60.

Tang, C. F. (2009). The Linkanges among Inflation, Unemployment and Crime Rates in Malaysia. International Journal of Economics and Management, 3(1), 50 -61. 
INTERNATIONAL JOURNAL OF ACADEMIC RESEARCH ECONOMICS AND MANAGEMENT SCIENCES Vol. 9, No. 2, 2020, E-ISSN: 2226-3624 @ 2020 HRMARS

Umair, M. (2019). The Socioeconomic Determinants of Crime in Pakistan. Budapest International Research and Critics Institute-Journal, 2 (3), 1-6. 